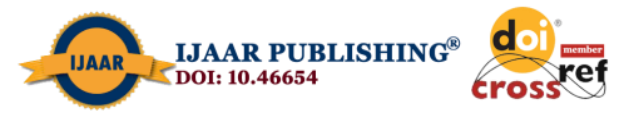

Journal DOI: 10.46654/ij.24889849

International Journal of Advanced Academic Research (Social and Management Sciences) | ISSN: 2488-9849

Vol. 6, Issue 10 (October, 2020) | www.ijaar.org

Article DOI: 10.46654/ij.24889849.s6109

\title{
ECONOMETRIC APPRAISAL OF AUDITORS' INDEPENDENT CHARACTERISTICS AND AUDIT QUALITY OF DEPOSIT MONEY BANKS IN NIGERIA
}

\author{
Sabo Ahmed and Alfred Anthony Kwanti \\ Department of Accounting, Taraba State University, Jalingo, Nigeria.
}

\begin{abstract}
The study examines the characteristics of auditor's independence on audit quality of Deposit Money Banks (DMBs) listed on the Nigerian Stock Exchange (NSE) from 2010 to 2019. A sample size of seven Deposit Money Banks was selected using the purposive sampling technique. The study used secondary data, sourced from the audited annual financial reports of the sampled banks. The analysis of the data was done using descriptive statistics, correlation matrix, and panel regression technique. The findings reveal that audit independence and audit firm rotation are positively related to audit quality, whereas audit firm tenure relates negatively to audit quality. The relationship between audit fees and audit quality is positively insignificant. The study recommends that audit firms are to be rotated after three years of service so as to avoid over-familiarity that may jeopardize the quality of audit reports. Also, the regulatory bodies should commence the enforcement of the three years audit tenure requirement proposed by stakeholders to forestall lengthy auditor/client relationship.
\end{abstract}

Keywords: Audit quality, Audit independence, Audit fee, Audit rotation, Audit tenure. 


\subsection{Introduction}

The management produces statutory financial statements that contain vital information that both internal and external users rely upon to make investment decisions. And since the owners (shareholders) of the business have no much knowledge of it and do not take part in running it, there is a need for the third party who is saddled with the responsibility of supervising and checking the work performed by the management to provide assurance that the information provided in the financial statements as presented to shareholders and other stakeholders are fair and are true representatives of the financial positions of the business (Zayol\&Kukeng, 2017). Hence, auditing and assurance services can be said to have emanated due to the function of the third party that bridges the gap between the owners of the business and the management as statutorily practiced worldwide.

Normally, the responsibility of examining the financial reports of organisations lies on the shoulders of auditors such that the stakeholders can ascertain if they reflect the true and fair view as they are meant to portray (Dabor \& Dabor, 2015). Therefore, the primary objective of an audit is the provision of an expert and independent opinion to the shareholders, affirming or otherwise that the annual financial statement of an organisation provided by the management reflects the true and fair view of its financial position, and whether it can be relied upon for investment decision making. However, the auditor must be independent of the client's company for him to provide an honest and unbiased professional opinion on the trueness and fairness of the financial reports to the shareholders, such that the relationship does not exert an undue influence on the audit opinion presented.

Therefore, the independence of an auditor is the ability of an external auditor to act with impartiality and integrity when executing his audit functions (Akpom\&Dimkpah, 2013). Though, sometimes doubts are being expressed regarding such independence as audit opinions and judgements are heavily influenced in order to sustain the relationship with the company. Where this situation occurs, the auditor can no longer be said to be independent and his opinion cannot be relied upon by the shareholders. This can be seen in the relationship between Enron and its auditor, Andersen Arthur in the year 2000, following the revelation that the latter received about \$27million for non-audit services as against \$25million for audit services (Ferdinand\& Fung, 2014). The auditing firm was accused of not acting independently after the demise of Enron. In Nigeria, a similar case of corporate and accounting scandals is witnessed in companies such as Afribank Plc, Oceanic Bank Plc, Bank PHB, Intercontinental Bank Plc, Cadbury Nigeria Plc, Savannah Bank Plc, African Petroleum (AP), Wema Bank Plc, and FinBank Plc, however, it is surprising to know that most of these distressed corporations had clean and verified reports before their eventual collapse (Dabor \& Dabor, 2015). Therefore, in line with the above findings, the independence of external auditors and the validity of financial reports are often called for questioning.

Several studies in Nigeria have made concerted efforts to examine the connection between the independence of auditor and audit quality in the audit market. Most of these studies which include Akpom andDimkpah (2013); Enofe, Mgbame, Okunega and Ediae (2013); Babatolu, Aigienohuwa and Uniamikogbo (2016); Oladipupo and Emife (2016), are of the opinion that length of audit tenure is one of the major factors affecting auditor's independence, such that Babatolu et al (2016) and Enofe et al. (2013) adopted audit tenure as a proxy for audit 
independence. However, there is an existence of several schools of thought in this regard, a group (such as Enofe et al, 2013) are of the opinion that lengthy tenure of an auditor could result in an opportunity cost of independence of auditor which is capable of undermining audit quality. Other groups comprising Tepalagul and Lin, (2015) argue that the independence of auditor and audit quality increase as the audit tenure increases since auditors require enough time to gain expertise in the audit business functions and to acquire the client's specific knowledge over time.

Furthermore, other researchers like Okolie (2014) and Babatolu et al (2016) opine that the amount of fee paid for an audit service could pose as a stumbling block for an auditor to exert his independence, they argue that the higher audit fee is charged, the likely increase in the economic bond between the auditor and the shareholders, thereby influencing the independence of the auditor (Okolie, 2014), whereas the audit firms that charge little fees might be influenced by the management of the company who may offer more money for the auditors to compromise their professionalism by undermining their independence.

In Nigeria, only a few empirical shreds of evidence from the study area are on deposit money banks (such as Enofe et al, 2013; \&Babatolu et al, 2016). Most of them examined audit numbers (number of the audit firm in an organization), audit fees, audit tenure as their independent variables, and audit quality as their dependent variable. This study will go a little further to include audit firm rotation as one of the independent variables. This is an indication that the researcher wants to add to the body of an already existing literature.

The main objective of this study is to appraise the econometric of auditor's independent characteristics and audit quality of deposit money banks in Nigeria. Other specific objectives include, to examine the extent to which audit independence relates to audit quality of deposit money banks in Nigeria, to evaluate the extent to which audit fee relates to audit quality of deposit money banks in Nigeria, to assess the extent to which audit firm rotation relates to audit quality of deposit money banks in Nigeria and lastly to determine the extent to which audit tenure relates to audit quality of deposit money banks in Nigeria. The study is expected to widen the body of literature on audit quality as well as providing solutions towards monitoring audit fees being charged by audit firms, which is a recent call on regulatory bodies in respect of auditor's independence.

\subsection{Literature Review}

\subsection{Audit Quality}

Knechel (2013) is of the view that audit quality is arguable but very difficult to understand because the processes of audit involve the implementation of testing procedures that the users of financial statements could not observe (DeAngelo, 1981; Hussainey, 2009). Audit quality is defined as a market-assessed joint probability that an auditor is capable of discovering a breach in the client's accounting system and as well report the breach (DeAngelo, 1981). The auditor's ability to detect error is a question of his competence, and the willingness to report such error is a question of his independence (Shafie 2009).

Audit quality is seen as the probability that an auditor will not present an audit report with an unqualified opinion for a financial statement that encompasses any material misstatement (Widiastuty\&Febrianto, 2010). Hussainey (2009) viewed audit quality as the accuracy of 
financial information provided by an auditor to users for investment decision making. Davidson and New (1993) defined audit quality as the capabilities of an auditor to detect and remove any manipulations and misstatements in the financial statements. Furthermore, the quality of an audit is determined by the auditor's competence in reducing biases and noises and in improving the quality of accounting data (Watkins, 2004).

This study defines audit quality as the ability of an auditor to discover and report any kind of errors contained in a financial statement. Discretionary accruals or aggressive income adjustments are the most common errors found in a financial statement. Discretionary accruals are those accruals that the management could manipulate with the intention of achieving the desired income or profitability. This could be done by the management that has control and the authority to create policies in the organization. Therefore, it is the obligation of an auditor to disclose discretionary accrual that is perceived not to be fair in order to prevent financial statement misstatement. Audit quality (AQ) is the dependent variable contained in this study. Hence, AQ = LOG of the total number of staff in the audit firm.

\subsection{Audit Independence}

Audit independence could be seen as an unbiased mental attitude of an auditor in making appropriate decisions throughout the course of the audit and reporting process. Sweeney (1994) refers to independence as the quality of being free from persuasion, influence, or bias, the absence of which will seriously weaken the value of audit service and the audit report. The lack of independence by an auditor increases the possibility of being perceived not to be objective, meaning that a discovered breach may not likely be reported by the auditor (Deangelo, 1981). Previous studies identified factors such as audit fee, non-audit service, audit tenure, level of competition, audit committee and size of the audit firm that are capable of affecting audit independence (Firth, 1980; Shocley, 1982; Gul, 1989; Craswell et al., 2000). This study applied audit fees to measure auditor's independence (AI); the natural log of the audit fee paid by the company.

\subsection{Audit Fees}

The amount of fees that auditors receive for their professional services ranging from factors such as the complexity of the services, the expertise level, and so on. Audit fees is defined by Agoes and Sukrisno (2012) as the amount of charge which depends among others, the complexity of the services provided, the risk of the assignment, the level of expertise that is required to execute the services to their proficient level, the structure of the firm's cost concerned and other considerations that are professional.

The audit fees referring to the cost of external audits denotes the amount of compensation given to external auditors for services performed or rendered. The compensation for the services relates to the length of time taken to complete the work and the expected value of the services that the firm or client is to receive. DeAngelo (1981) opined that the cost of external audit or audit fee varies significantly. Similarly, Al-Shammari et al. (2008) argued that the external audits cost can be viewed also as the function of the level of work performed by the auditors or the level of the service required and the price per hour. 
It is found that when auditors negotiate with management as regard the audit fees that should be paid relating to the work performed, there could be likelihood of clear mutual concession that would reduce the quality of the audited financial statements (Hoitash et al. 2007). Lestari (2013) opines that the fair value of the audit tasks conducted by auditors are the reflection of the audit fees.

\subsection{Audit Tenure}

This study defined audit tenure as the relationship that exists between an auditor and the client over a period of time. A relatively long relationship between the auditor and the client may pose a threat to the independence of the auditor as familiarity and personal ties may develop, which may result in less vigilance on the part of the auditor, thereby compromising or yielding to the demand of the management. Apart from the threat to independence, audit engagement may be routinely carried out, and if this happens, less effort may be devoted by the auditor to identify weaknesses of risk sources and internal control (Okolie, 2014).

Audit tenure has been viewed as long and short audit periods. Long audit periods may diminish the independence and professionalism of an auditor, while short audit tenure may ensure that the auditor has less knowledge about the client's operations which may lead to low audit quality. A long audit tenure may enhance the knowledge of the auditor about the client's internal operations, but the effect is that the independence of the auditor may be compromised (Islam, 2016; Feleke, 2017). On the other hand, the clients change their auditors for so many reasons; one such is the reduction of audit fees from the new auditor who may offer services at a discount in order to lure new clients (Franken, 2011; Oladipupo \& Emina, 2016).

This study measured audit tenure (AT) as the length of auditor-client association; ' 1 ' if 3 years and above, and ' 0 ' if otherwise.

\subsection{Audit Firm Rotation}

Rotation of auditors is one of the many factors affecting auditor independence and audit quality. Hence, to avoid long term relationships and familiarity, audit rotation among external auditors has been proposed by the regulatory bodies (Al-Khoury et al, 2015). Audit rotation occurs in two forms; mandatory rotation and voluntary rotation.

The length of time an auditor is required to stay with the client is referred to as mandatory rotation. The auditor is required to be rotated after a specified number of years despite exhibiting good qualities of independence, objectivity, and efficiency, and the shareholders and management willingness to sustain the relationship (Onwuchekwa et al, 2012). The general belief is that the long relations and familiarity between the external auditor and the client will reduce through audit rotation, thereby enabling auditors to take a new valuation of client's risks, support much-needed skepticism, and explore other perspectives that might enhance auditor's independence and audit quality (Al-Nimer, 2015; Ball, Tyler \& Wells, 2015).

This study measured audit firm rotation (AFR) as ' 1 ' if there is audit firm rotation and ' 0 ' if otherwise. 


\subsection{Audit Independence and Audit Quality}

Previous studies affirm that the economic bond between the auditor and the client increases because of the high audit fees being paid by the company, and consequently, the independence of the auditor may be impaired (Frankel et al, 2002; Li and Lin, 2005). The resultant effect of this impaired independence is poor audit quality which allows for higher earnings management and lesser earnings quality (Okolie, 2014).

Craswel, Stokes, and Laughton (2002) observed that audit independence may be related to audit fees. Applying the tendency of an auditor to issue a qualified audit report as a measure of the ratio of audit fee to the total national fee of the audit firm. Furthermore, Craswelet al., (2002) reasoned that an auditor may be willing to issue a qualified audit opinion regardless of the economic importance of the client to him, in a situation where it is mandatory to publicly disclose audit and non-audit fees.

Independence is a major quality of an auditor that ensures he does not develop any personal interests in carrying out his job, because it will go against his principles of objectivity and integrity (Arens2010). An audit opinion will be useless if an auditor is not independent of his client, as the main aim of the opinion is to give more credibility to the financial statement as presented by the management (Arens, 2010). Another research conducted by Alim (2007) showed empirically how the independence of an auditor can affect audit quality.

\subsection{Audit Tenure and Audit Quality}

A lengthy relationship between the audit firm and a company might lead to intimacy that will make it difficult for the former to express his professional opinion freely (Bamber\&Iyer, 2007). Prior studies conducted by Geiger and Ragunandan (2002); Defond et al. (2002); Carcello and Nagy (2004); Bamber and Iyer, (2007) showed that a prolonged audit tenure results in a lower tendency of issuing a qualified audit report. Lack of innovation, complacency, less confidence, and less rigorous audit procedures might arise after a lengthy auditor- client relationship (Shockley, 1982). Professional accounting bodies such as ICAA and CPA Australia (2001), AICPA (1978 and 1992), and Coordinating Group on Audit and Accountant Issues (2003) have also expressed worries that lengthy audit-client association may weaken audit quality.

Palmrose (1988) views audit quality as a confirmation of assurance. Certainly, the main reason for an audit is to provide an assurance to the fairness and trueness of financial statements, and the level of assurance that the financial statement is devoid of any material misstatements is the quality of the audit.

Knapp (1991) conducted an experimental study where he established a link between competence and audit tenure in the United States. The US audit committee observed that the tendency of the auditor detecting anomalies in the financial statement increases in the first years of his obligation, and gradually decreases, eventually reaching its weakest after twenty years in the service. Therefore, it is generally perceived that negative association is normally anticipated between audit tenure and audit quality. 


\subsection{Audit Firm Rotation and Audit Quality}

The study conducted by Okolie (2014), showed that audit firm rotation is positively significant with audit quality as they used discretionary accrual as a proxy of audit quality. A company that rotates its audit firm over a stipulated period of time is capable of enhancing the independence of its auditor thereby generating a quality audit report. Alternatively, Kammenga (2016) and Postma (2016) used the same variables in their studies but found audit firm rotation not to be significant with audit quality.

Oladipupo and Emina (2016) and Feleke (2017) in their studies where primary data in form of questionnaires were issued to respondents, found the relationship between audit firm rotation and audit quality to be negatively significant. On the other hand, in the studies of Enofe et al., (2013) and Babatolu et al., (2016), the relationship is positively significant.

\subsection{Agency Theory}

Watts and Zimmerman (1986) submit that an auditor is appointed to serve the interests of both the shareholders and the management. Hence, a company is seen as a web of contracts. Some groups such as customers, suppliers, bankers, and employees contribute to the company in their own unique ways for a given price. The management is responsible for coordinating these groups and contracts and optimize them in ways such as achieving minimum costs of supplies, high and competitive prices for goods and services it provides, low-interest rates for loans, low wages for employees and high share prices. In this kind of relationship, the management is the agent who solicits contributions from the shareholders (principals or owners of the company) and other stakeholders like bankers, suppliers and employees.

\subsection{Stakeholder Theory}

The stakeholder theory evolved from agency theory. The assumption of the theory is that the survival of an entity does not lie only on the relationship between the agents and their principals, the relationship extends to other individuals that have stakes in the running of the organization. Such individuals include creditors, bankers, the host community, and the government. Therefore, it means there is a greater demand of information relating to the organization, and it is the responsibility of the external auditor to ensure that quality financial statements are prepared by the management (Freeman, 1984; Jones, 1995; Donaldson \& Preston, 1995; Jones \& Wicks, 1999).

\subsection{Methodology}

The research design adopted for this study is descriptive and historical. A panel data analysis was adopted, considering that the data constitute both the characteristics of times series and crosssectional. The population of this study comprised of the twenty-two (22) deposit money banks listed on the Nigerian Stock Exchange. A sample size of seven (7) deposit money banks out of the twenty-two (22) was selected using the purposive sampling technique over a period of ten years, from 2010 to 2019 accounting year. This study used secondary data that were sourced from the audited annual reports of the sampled deposit money banks in Nigeria. The techniques for data analysis adopted in this study comprise of multiple regression using fixed effects and random-effects models of estimation and correlation. STATA 13 was used to run the analyses. 


\subsection{Model Specification and Measurement of Variables}

$$
\text { AQit }=\beta_{0}+\beta_{1} \text { Alit }+\beta_{2} \text { AFit }+\beta_{3} \text { ARit }+\beta_{4} \text { ATit }+ \text { eit }
$$

Where:

$\mathrm{AQ}=$ Audit Quality

$\mathrm{AI}=$ Audit Independence

$\mathrm{AF}=$ Audit Fees

$\mathrm{AR}=$ Audit Rotation

$\mathrm{AT}=$ Audit Tenure

$\beta 0=$ Intercept

$\mathrm{e}=$ Error term

Table 1 Measurement of Variables

\begin{tabular}{|c|c|c|c|c|c|}
\hline $\mathrm{S} / \mathrm{N}$ & Variable & Definition & Type & Measurement & Author \\
\hline 1 & $\mathrm{AQ}$ & Audit Quality & Dependent & $\begin{array}{l}\text { Natural log of the total } \\
\text { number of staff in the } \\
\text { audit firm. }\end{array}$ & $\begin{array}{l}\text { Enofe et al., (2013), } \\
\text { Babatolu et al. (2016) }\end{array}$ \\
\hline 2 & $\mathrm{AI}$ & $\begin{array}{l}\text { Audit } \\
\text { Independence }\end{array}$ & Independent & $\begin{array}{l}\text { The ratio of audit fees } \\
\text { to the company's } \\
\text { revenue. }\end{array}$ & $\begin{array}{l}\text { Adeniyi et al (2013), } \\
\text { Enofe et al. (2013) }\end{array}$ \\
\hline 3 & $\mathrm{AF}$ & Audit Fee & Independent & $\begin{array}{l}\text { Natural log of audit } \\
\text { fee paid by the } \\
\text { company. }\end{array}$ & $\begin{array}{l}\text { Babatolu et al. } \\
(2016), \\
\text { Enofe et al. (2013) }\end{array}$ \\
\hline 4 & AR & $\begin{array}{l}\text { Audit } \\
\text { Rotation }\end{array}$ & Independent & $\begin{array}{l}\text { ' } 1 \text { ' if there is audit } \\
\text { firm rotation and ' } 0 \text { ' if } \\
\text { otherwise. }\end{array}$ & $\begin{array}{l}\text { Babatolu et al. } \\
(2016), \\
\text { Enofe et al. (2013) }\end{array}$ \\
\hline 5 & $\mathrm{AT}$ & Audit Tenure & Independent & $\begin{array}{l}\text { Length of auditor- } \\
\text { client relationship ' } 1 \text { ' } \\
\text { if } 3 \text { years and above } \\
\text { and ' } 0 \text { ' if otherwise. }\end{array}$ & $\begin{array}{l}\text { Bafqi et al (2013), } \\
\text { Babatolu et al. (2016) }\end{array}$ \\
\hline
\end{tabular}

\subsection{Results and Discussion}

The analysis of the descriptive statistics, correlation, and regression results are presented in the sub-sections that follow: 
Table 2: Descriptive Statistics

\begin{tabular}{r|rrrrr} 
Variable & Obs & Mean & Std. Dev & Min & Max \\
\hline aq & 70 & .761226 & .066478 & .4771213 & .845098 \\
ai & 70 & 5.828571 & .7217416 & 3 & 7 \\
af & 70 & 7.428247 & 3.098679 & 3.218873 & 12.89921 \\
ar & 70 & .8285714 & .3796042 & 0 & 1 \\
at & 70 & .8428571 & .3665631 & 0 & 1
\end{tabular}

\section{Source: STATA 13 (2020)}

The above table 2 shows the characteristics of the seven (7) money deposit banks that constitute the total sample of the study. Audit quality is represented here by the natural log of the actual amount of the audit fees (proxy). It is observed that the mean value of the audit quality (AQ) stands at 0.761226 which implies that the total audit fee paid by the money deposit banks during the period constitutes $76 \%$, with the minimum value at $47 \%$ and the highest at $84 \%$. The standard deviation of 0.066478 , not too far from the mean, shows a minimal dispersion from the mean of the audit fee. The results for audit independence show a mean value of 5.828571, a standard deviation of 0.7217416, a minimum of 3 and a maximum of 7 . The mean value of the total audit fee is 7.428247 , standard deviation at 3.098679 , minimum value at 3.218873 , and maximum value at 12.89921 . The results also show that $82 \%$ of the deposit money banks in question rotate their auditors which are very encouraging in achieving audit independence. Lastly, the result for audit tenure shows a mean value of 0.8428571 , which means that $84 \%$ of the sampled money deposit banks have retained their audit beyond three years.

Table 3: Correlation Matrix

\begin{tabular}{r|rrrrr} 
& aq & ai & af & ar & at \\
\hline aq & 1.0000 & & & & \\
ai & $0.9943^{*}$ & 1.0000 & & & \\
af & $-0.5112 *$ & $-0.5173 *$ & 1.0000 & & \\
ar & -0.1096 & -0.1088 & -0.0068 & 1.0000 & \\
at & -0.0636 & -0.0485 & -0.0444 & $0.9493 *$ & 1.0000
\end{tabular}

\section{Source; STATA 13 (2020)}

Table 3 above presents the analysis of the correlation between the variables used in this study. The analysis shows that there is no relationship between the dependent variable audit quality (AQ) with audit independence (AI), audit fee (AF) and audit rotation (AR): AI ( $\mathrm{r}=.099), \mathrm{AF}(\mathrm{r}$ $=-0.51)$ and $\mathrm{AR}(\mathrm{r}=-11 \%)$. Alternatively, there is a negatively weak correlation between AQ and AT at $6 \%$. Based on the correlation among the independent variables, AR and AF have a strong relationship at -0.0068 , AT relates with AI at -0.0485 and AT and AR at (-0. 0444). There was an absence of high correlation among the variables which could have indicated a problem of multicollinearity. Therefore, the variables adopted are perfectly suited for estimating the regression.

The fixed effects and random effectstechniques were adopted to provide a comprehensive overview of the results. The fixed effects and the random effectstechniques were preferred over 
pooled OLS for the fact that they recognize the heterogeneity or individuality that may exist among the sampled companies. Thereafter, the Hausman test was carried out to select the most appropriate technique between the fixed effects model and the random-effects model.

\section{Table 4: Hausman Test}

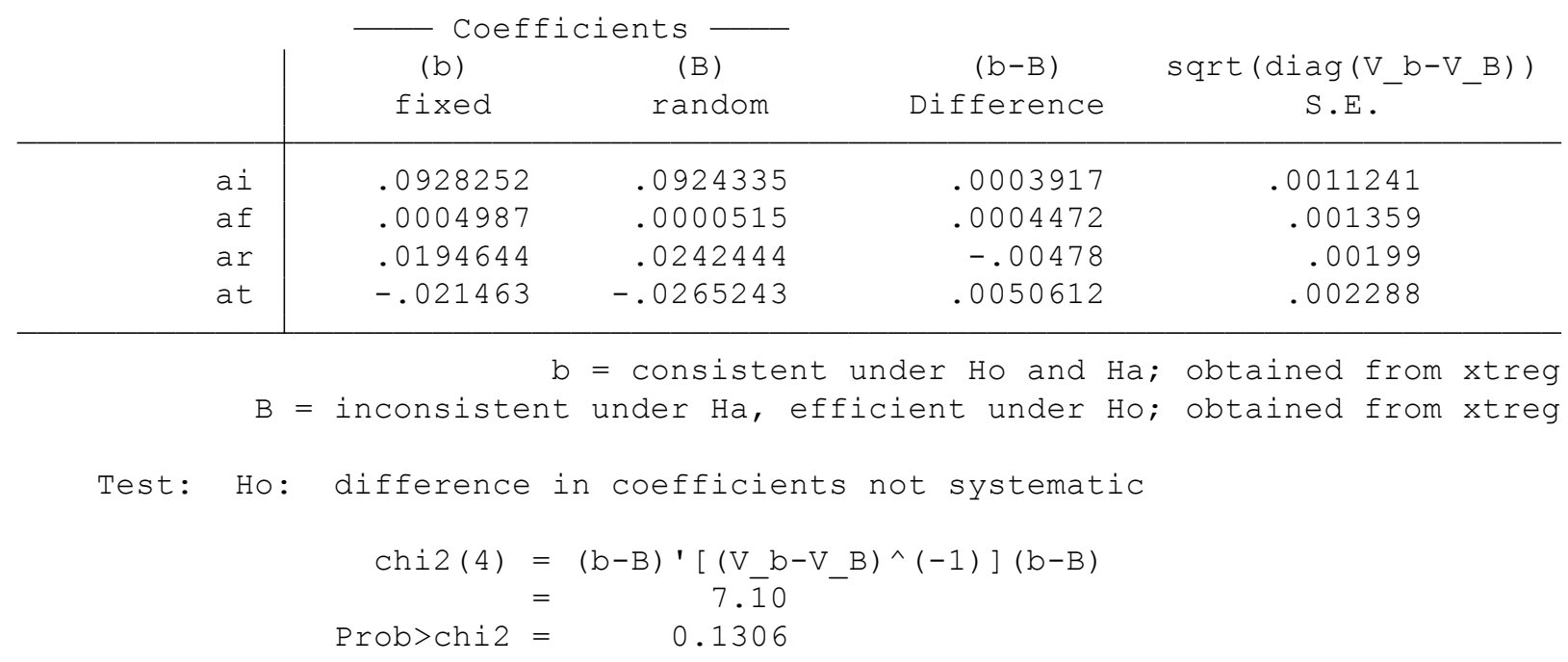

\section{Source; STATA 13 (2020)}

Hausman test is performed on panel data to determine the most suited model between the fixed effects model and the random-effects model. The following hypotheses are applied; Horandom effects model is consistent and Hafixed effects model is also consistent. Based on the decision rule, since the p-value is greater than 5 percent, the null hypothesis is accepted that the random effect model is consistent. Therefore, the outcome of the result indicates that the probability value of 0.1306 is greater than 5\%, which confirms the appropriateness of the random effects model necessary for analysing the relationships among the variables. 


\section{Table 5: Results of Random Effects Model}

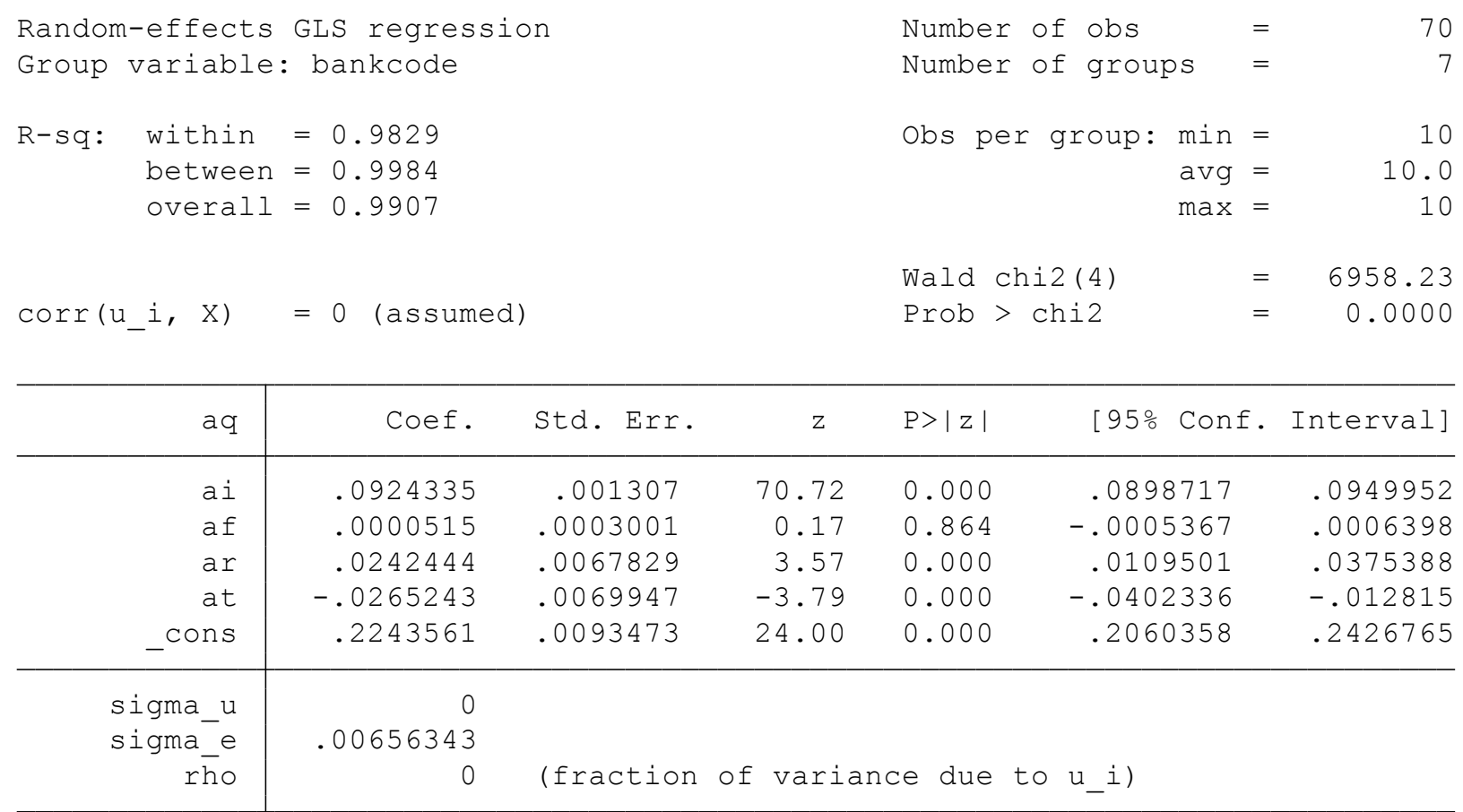

\section{Source; STATA 13 (2020)}

Table 5 above shows the statistical significance of the model at less than $1 \%$ (p-value $=0.0000$ ). The $\mathrm{R}$ squared which explains the degree of successive inclusion of the explanatory variables adopted in the study stands at $99 \%$. This implies that the remaining variables not captured by the model constitute only $1 \%$ which is taken care of by the error term.

The coefficients of the independent variables show that there are positive significant relationships between audit independence (AI), audit rotation (AR) with audit Quality (AQ) at coefficients of 0.0924335 and 0.0000515 respectively and p-value of (0.0000). On the other hand, the relationship between audit tenure (AT) and AQ is negatively significant at a coefficient of 0.2243561 and a p-value of 0.0000 , whereas the relationship between audit fee (AF) and AQ is positively insignificant at a level of $0.864 \%$ and coefficient of 0.0000515 . The relationship between audit fees (AF) and AQ is positively insignificant. The interpretation of these results isthat the higher the audit independence, the rotation of external auditors in deposit money banks in Nigeria, the higher the quality of audit reports that will be generated. However, the negatively significant relationship between AT and AQ denotes that the higher the audit tenure the lower the quality of audit that will be generated, and vice versa.

Based on the results of the empirical review conducted earlier, the positive significant relationship between audit independence and audit quality found in this study is consistent with the studies of (Okolie, 2014 \&Arens, 2010), which validates the strong dependence of audit quality on audit independence to generate quality audit report. As opined that it is the only major quality of an auditor that ensures he does not develop any personal interests and relationships in 
conducting his audit job, contrary to that, it will go against his principles of objective and integrity.

Similarly, the relationship between audit firm rotation and audit quality is positively significant. The finding validates the submission of Babatolu et al. (2016), Kammenga (2016) and Postma (2016) that rotation of audit firms on regular basis will most likely enhance audit quality, because regular rotation can help to checkmate some activities of the auditor that are capable of posing threats to their independence thereby undermining audit quality.Chika et al (2012) also supported this positive relationship, further argued that rotation of audit is a way of improving audit quality because too much intimacy between the auditor and a client could lead to non-audit services that can influence the auditor's judgemental reasoning and application of fresh points or ideas.

The results further showed there is an inverse relationship between audit tenure and audit quality, meaning that the longer the period an auditor stays engaged with the client or company, the more likely that the quality of the functions of the audit will be lower, whereas the lower the audit tenure the likelihood of the quality of audit soaring high. The negative sign obtained in this study is consistent with the studies of Babatolu et al. (2016) and Adeniyi and Mieseigha (2013) who found that audit quality is impaired by longer audit firm tenure.

\subsection{Conclusion and Recommendations}

This study examined the relationships between the characteristics of auditor's independence and audit quality. Four independent variables (audit independence, audit fee, audit firm rotation, and audit firm tenure) were employed to capture the characteristics of auditor independence and the regression analysis was obtained against the dependent variable (audit quality). The study reveals positively higher relationships between audit independence, audit firm rotation with audit quality. This implies that the higher the audit independence and audit firm rotation, the higher the quality of the audit report.

Contrary to the above findings, the audit firm tenure has an inversely negative relationship with audit quality, meaning that the longer an auditor stays in a company, the lower the quality of audit report and vice versa. Therefore, it is recommended that since audit tenure influences audit quality negatively, the enforcement of the proposed three years of audit tenure requirement should commence preventing lengthy auditor-client association which could jeopardize the independence of an auditor. Additionally, the promotion of frequent audit firm rotation should be encouraged to minimize auditor-client intimacy which may adversely affect audit independence. Lastly, auditors are advised in their best interest to uphold their principles of integrity and objectivity in order to act independently of their clients. 


\section{Reference}

Adeniyi, S. I., \&Mieseigba, E. G (2013). Audit tenure: An assessment of its effects on audit quality in Nigeria. International Journal of Academic Research in Accounting, Finance and Management Sciences, 3(3), 275-283.

Agoes, Sukrisno. (2012). Auditing (Accountants Examination) by Public Accounting Firm. Volume I. Third Edition. Jakarta: Issuing Faculty of Economics, University of Indonesia.

Akpom, U.N., \&Dimkpah, Y.O. (2013). Determinants of auditor independence: A comparison of the perceptions of auditors and non-auditors in Lagos, Nigeria. Journal of Finance and Accountancy, 12(9), 1-17.

Alim, M. N, Trisni, H, and Lilik, P. (2007). The effect of competence and independence to the audit quality, Proceedings of national accounting symposium x, Indonesian Accounting Association, Makassar, Indonesia, 31-48.

Al-Khoury, A. F., Ali, A. E., Al-Sharif, M., Hanania, J., Al-Malki, I., \&Jallad, M. (2015). Auditor independence and mandatory auditor rotation in Jordan. International Business Research, 8(4), 73.

Al-Nimer, M. (2015). Factors affecting mandatory audit rotation: evidence from Jordan. International Journal of Economics and Finance, 7(6), 51.

Al-Shammari, B., Abdullah Al-Yaqout, and Ahmad al-Husaini. 2008. Determinants of audit fees in Kuwait. Journal of the Academy of Business and Economics. Vol 8 (1).

Arens, A. A, Elder, RJ, and Beasley, MS 2010, Auditing and assurance services: an integrated approach, 13th eds, Prentice Hall Inc., New Jersey.

Babatolu, A.T., Aigienohuwa, O.O., \&Uniamikogbo, E. (2016). Auditor ${ }^{\text {ee }}$ independence and audit quality: A study of selected deposit money banks in Nigeria. International Journal of Finance and Accounting, 5(1), 13-21.

Bafqi, H. D., Addin, M. M., \&AlaviRad, A. (2013). The relationship between auditor's characteristics and audit quality. Interdisciplinary Journal of Contemporary Research in Business, 5(3), 639-648.

Ball, F., Tyler, J., \& Wells, P. (2015). Is audit quality impacted by auditor relationships? Journal of Contemporary Accounting \& Economics, 11(2), 166-181.

Bamber, M.E, and Iyer, V.M. (2007). Auditors' Identification with their clients and their effect on auditors' objectivity. Journal of Practice and Theory, 26 (2)1-24.

Carcello, J.V., and Nagy, A. L. (2004). Audit firm tenure and fraudulent financial reporting. Working Paper, University of Tennessee.

Craswel, A., Stokes, D. J., and Laughton, J. (2002). Auditor independence and fee independence, Journal of Accounting and Economics, 33, 253 - 275.

Dabor, E.L., \&Dabor, A.O. (2015). Audit committee characteristics, board characteristics, and financial reporting quality in Nigeria. International Journal of Economics, Commerce and Management, 3(11), 1292-1304.

Davidson, A. R, and New, D. (1993). A note on the association between audit firm size and audit quality". Contemporary Accounting Research, 9(2), Spring, 479-488.

DeAngelo, L. E. (1981). Auditor size and audit quality, Journal of Accounting and Economics, 3 (3), $183-199$. 
DeAngelo, LE (1981). "Size and Auditor Quality Auditor"Journal of Accounting and Economics, Dec, Vol.3, No.3: 183-199.

DeFond, M. L., Raghunandan, K., and Subramanyam, K.R. (2002). Do non-audit service fees impair auditor independence? Evidence from going concern audit opinions. Journal of Accounting Research, 40, 1247- 1274.

Donaldson, T and Preston, I. (1995). The stakeholder theory of the corporation: Concepts, evidence, implications. Acad. Manage. Rev. 20:65-91.

Ebimobowei, A., \&Keretu, O. J. (2011). Mandatory rotation of auditors on audit quality, costs, and independence in South-South, Nigeria. International business management, 5(3), $166-172$.

Enofe, A.O., Mgbame, C., Okunega, E.C., \&Ediae, O.O. (2013). Audit quality and auditors' independence in Nigeria: An empirical evaluation. Research Journal of Finance and Accounting, 4(11), 131-138.

Feleke, B. T. (2017). Auditors' Perception of Audit Quality in Ethiopia (Doctoral dissertation, Addis Ababa University).

Ferdinard, A. G., \& Fung, S. (2014). Hong Kong Auditing: Economic Theory \& Practice.Third Edition. City University of Hong Kong Press.

Firth, M. (1980). Perceptions of auditor independence and official ethical guidelines.The Accounting Review, 51-66.

Frankel, R., Johnson, M., and Nelson, K. (2002). The relation between auditors' fees for non audit services and earnings quality.The Accounting Review 77 (Supplement), 71-105.

Franken, N. E. (2011). The influence of investor protection on the relationship between positive abnormal audit fees and earning quality (Doctoral dissertation, Master Thesis, the University of Tilburg. Netherland). Retrieved from http://unsw. edu. au).

Freeman, R. E (1984). Strategic management: a stakeholder approach. Boston, Pitman.

Geiger, M. A., and Raghunandan, K. (2002). Auditor tenure and audit reporting failures, Auditing: A Journal of Practice and Theory, 21(1), 67-78.

Gul, F.A. (1989). Banker's perceptions of factors affecting auditor independence, Accounting, Auditing, and Accountability Journal, 2(3), 40-51.

Hoitash, R. and U. Hoitash. 2007. The Role of Audit Committees in Managing Relationship with External Auditors After SOX: Evidence from US American Accounting Association Annual Meeting and Accounting Research Workshops Bentley College and Suffolk University.

Hussainey, K. (2009). The impact of audit quality on earnings predictability. Managerial Auditing Journal, 24(4), 340-351.

Islam, M. S. (2016). Impact of non-audit services and tenure regulations on auditor independence and financial reporting quality: Evidence from the UK (Doctoral dissertation, Cardiff University).

Jones, T. M. (1995). Instrumental stakeholder theory: A synthesis of ethics and economics. Acad. Manage. Rev. 20, 404-437.

Jones,T. M. and Wicks, A. C. (1999). Convergent stakeholder theory. Acad. Manage. Rev. 24(2):206-221. 
Kammenga, M. (2016). Audit firm-client relationship: influence of audit firm tenure and audit firm switching on the audit quality of client firms in Italy.

Kingstone, T., Burroughs, H., Bartlam, B., Ray, M., Proctor, J., Shepherd, T. \& Chew-Graham, C. A. (2017). Developing a community-based psycho-social intervention with older people and third sector workers for anxiety and depression: a qualitative study. $B M C$ family practice, $18(1), 77$.

Knapp, M. C. (1991). Factors that audit committee members use as a surrogate for audit quality, Auditing: A Journal of Practice and Theory, 10 (1), 35 - 52.

Knechel, R. W., Krishnan, V. G., Pevzner, M., Shefchik, B. Lori, danVelury, K. Uma. (2013). Audit Quality: Insights from the Academic Literature, Auditing: A Journal of Practice and Theory.32, Supplement: 385-421.

Lestari, V. 2013. The evidence on the impact of internal controls and good corporate governance to the audit fee. Thesis. Jakarta. SyarifHidayatullah State Islamic University.

Li, J., and Lin, J. (2005). The relationship between earnings management and audit quality. Journal of Accounting and Finance Research, 12 (1), 1- 11.

Okolie, A.O. (2014). Auditor tenure, auditor independence, and accrual-based earnings management of quoted companies in Nigeria: European Journal of Accounting Auditing and Finance Research, 2(2), 63-90.

Oladipupo, A.O., \&Monye-Emina, H.E. (2016). Do abnormal audit fees matter in the Nigerian audit market? International Journal of Business and Finance Management Research, 4(6), 64-73.

Onwuchekwa, J. C., Erah, D. O., \&Izedonmi, F. (2012). Mandatory audit rotation and audit quality: Survey of Southern Nigeria: Research Journal of Finance and Accounting, 3(8), $70-77$.

Palmrose Z (1988). An analysis of auditor litigation and audit service quality. Account. Rev. 63(1): 55-73.

Postma, E. (2016). The effects of audit firm rotation on audit quality: does audit firm rotation improve audit quality? (Master's thesis, University of Twente).

Shafie, Rohami, Wan Nordin, Wan Hussin, Mohd, 'Atef, Md. Yusof and Md. Hairi, Md. Hussin (2009). Audit Firm Tenure and Auditor Reporting Quality: Evidence in Malaysia. International Business Research, 2(2), 99-109.

Shockley, R.A. (1982). Perceptions of auditors' independence: an empirical analysis, The Accounting Review. 56(4), 785-800.

Sweeney, A.P. (1994). Debt-Covenant violations and managers' accounting responses. Journal of Accounting and Economics, 17, $281-308$.

Tepalagul, N., \& Lin, L. (2015). Auditor Independence and Audit Quality A Literature Review. Journal of Accounting, Auditing \& Finance, 30(1), 101-121.

Uniamikogbo, E. (2019). Forensic audit and fraud detection and prevention in the Nigerian banking sector.

Watkins, A.L. W. Hillison, and S.E. Morecroft. (2004). Audit quality: a synthesis of theory and empirical evidence. Journal of Accounting Literature. 23, 153-193.

Watts, R, and J. Zimmerman (1986). The demand for and supply for accounting theories. The Accounting Review 54(2), 273-305. 
International Journal of Advanced Academic Research (Social and Management Sciences) | ISSN: 2488-9849 Vol. 6, Issue 10 (October, 2020) | www.ijaar.org

Journal DOI: 10.46654/ij.24889849

Article DOI: 10.46654/ij.24889849.s6109

Widiastuty, E and Febrianto, R. (2010). Audit quality measurement: An essay: Accounting and Business Journal, (2), 1-20.

Zayol, P.I., \&Kukeng, V.I. (2017). Effect of auditor independence on audit quality: A review of the literature. International Journal of Business and Management Invention, 6(3), 51-59. 